\title{
Surface Water and Groundwater Quality Evaluation in a Mining Area
}

\author{
ALINA COCHIORCA ${ }^{1}$, VALENTIN NEDEFF ${ }^{1,2}$, NARCIS BARSAN ${ }^{1 *}$, ION SANDU ${ }^{3,4}$, \\ EMILIAN MOSNEGUTU ${ }^{1 *}$, DANA ALEXANDRA CHITIMUS ${ }^{1}$, \\ ANDREI VICTOR SANDU ${ }^{5,6}$, OANA IRIMIA ${ }^{1}$ \\ ${ }^{1}$ Vasile Alecsandri University of Bacau, Faculty of Engineering, 157 Calea Marasesti, 600115, Bacau, Romania \\ ${ }^{2}$ Gheorghe Ionescu Sisesti, Academy of Agricultural and Forestry Sciences Bucharest, 61 Marasti Blvd., 011464, \\ Bucharest, Romania \\ ${ }^{3}$ Alexandru Ioan Cuza University of Iasi, Arheoinvest Interdisciplinary Platform, Scientific Investigation Laboratory, 11 \\ Carol I Blvd., 700506, Iasi, Romania \\ ${ }^{4}$ Romanian Inventors Forum, 3 Sf. Petru Movila Str., Bloc L11, III/3, 700089, Iasi, Romania \\ ${ }^{5}$ Gheorghe Asachi Technical University of Iasi, Materials Science and Engineering Faculty, 53A D. Mangeron Blvd., \\ 700050, Iasi, Romania \\ ${ }^{6}$ National Institute for Research and Development in Environmental Protection, 294 Splaiul Independentei Blvd., 060031, \\ Bucharest, Romania
}

\begin{abstract}
This paper presents a monitoring of groundwater and surface water in the mining area Tg. Ocna, by analyzing 16 physico-chemical parameters ( $\mathrm{pH}$, turbidity, dissolved oxygen, $\mathrm{Pb}, \mathrm{Ni}, \mathrm{Cu}, \mathrm{Fe}$, $\left.\mathrm{Mn}, \mathrm{Zn}, \mathrm{Cr}, \mathrm{Mg}, \mathrm{SO}_{4}^{2-}, \mathrm{Al}, \mathrm{NO}_{2}^{-}, \mathrm{NO}_{3}^{-}, \mathrm{NH}_{4}^{+}\right)$, from three rivers Slanic, Trotus and Valcele, a small lake Groapa Burlacu, a fountain and three monitoring drilling wells (F11, F16 and F17). Studies on the quality of surface water and groundwater in areas near mines are important due to extraction and exploitation of salt. The samples were collected in April 2019. Following the analyzes, their results are included in the following concentration ranges: $p H 7.21$ to 8.46 unit. $p H$, turbidity 0.54 to $169 \mathrm{NTU}$, dissolved oxygen 6 to $8.59 \mathrm{mg} / \mathrm{L}, \mathrm{Pb} 0.075$ to $0.095 \mathrm{mg} / \mathrm{L}$, Ni 0.026 to $1.05 \mathrm{mg} / \mathrm{L}, \mathrm{Cu} 0.088$ to 0.809 $\mathrm{mg} / \mathrm{L}, \mathrm{NO}_{2}^{-} 0.001$ to $0.037 \mathrm{mg} / \mathrm{L}$ and $\mathrm{NO}_{3}^{-} 0.290$ to $4.34 \mathrm{mg} / \mathrm{L}$. The $\mathrm{pH}$, turbidity and dissolved oxygen were measured in situ using portable equipment's. As for the other parameters, they were analyzed in the water laboratory from Vasile Alecsandri University of Bacau by using spectrophotometry. Some concentrations of the physico-chemical indicators of the water samples analyzed were found to be more than the water quality classes.
\end{abstract}

Keywords: water quality analysis, groundwater and surface water sources, mining area

\section{Introduction}

Surface water and groundwater are an important water resource for different activities. Due to the urbanization, industrialization and other anthropic activities (unproper wastewater treatment and water resource management, agriculture etc), the quality of surface water and groundwaters are very affected [1-14]. Another factor that can leads to exhaustion of surface water resources may also be due to its unequal worldwide distribution. Due to these factors that lead to exhaustion of surface water resources, groundwater is used for different requirements and industry sectors [15-30]. In order, to protect the quality of groundwater against pollution, at European level, a directive was implemented in 2006, which helps them with European Commission Directive 2006/118/EC [31].

Regarding the quality of the groundwater, the physical-chemical properties monitoring can be the best methods for punctual or global quality evaluation. Besides these properties there are other parameters that can change the quality of groundwater, for example metals. The main sources of pollution with metals of the water are the untreated wastewater discharges, the industrial and mining activities, the agricultural activities etc. [32-45].

The mining exploitation, in most countries, is an important economic activity essential to supply raw materials for human activities. Within this activity, the operations used can produce large

\footnotetext{
*email: narcis.barsan@ub.ro,emos@ub.ro
} 
quantities of waste, pollution of water surface and groundwater, land degradation, evacuation of mining water which can affect the environment for a longer period [23, 32]. Also, the surface water and groundwater quality investigation in mines areas are important to maintain a proper evaluation of the water sources and the pollution incidence dynamic.

This paper presents a groundwater and surface water monitoring in the Tg. Ocna Bacau mining area, by analyzing 16 physico-chemical parameters $(\mathrm{pH}$, turbidity, dissolved oxygen, $\mathrm{Pb}, \mathrm{Ni}, \mathrm{Cu}, \mathrm{Fe}$, $\mathrm{Mn}, \mathrm{Zn}, \mathrm{Cr}, \mathrm{Mg}, \mathrm{SO}_{4}{ }^{2-}, \mathrm{Al}, \mathrm{NO}_{2}^{-}, \mathrm{NO}_{3}{ }^{-}$and $\mathrm{NH}_{4}{ }^{+}$), from three rivers (Slanic, Trotus and Valcele), a small lake (Groapa Burlacu), a fountain and three monitoring drilling wells placed in the area of mining activity F11, F16 and F17.

\section{Materials and methods}

\subsection{Study Area}

The city of Targu Ocna is in the southwest of Bacau county, on the banks of the Trotus river, where it receives the waters of the Slanic and Valcele affluent. The geographical coordinates of the study area are $46.2876^{\circ} \mathrm{N} 26.6034^{\circ} \mathrm{E}$. The studied area is near the Targu Ocna salt mine, which includes a salt solution section exploitation area. Since the area is located between mountains and hills, the thermal regime is a moderate one with mild winters with early spring and cool summers with an average annual temperature of $9.3^{\circ} \mathrm{C}$.

Surface water and groundwater samples (Figure 1) were collected from 11 different points within the Slanic River, upstream and downstream (RSU and RSD), the Trotus River, upstream and downstream (RTU and RTD), the Valcele River, upstream and downstream (RVU and RVD), a fountain, and three drilling monitoring points (F11, F16, F17), from the city of Targu Ocna. The monitoring points were chosen for a good water quality evaluation before and after mining area.

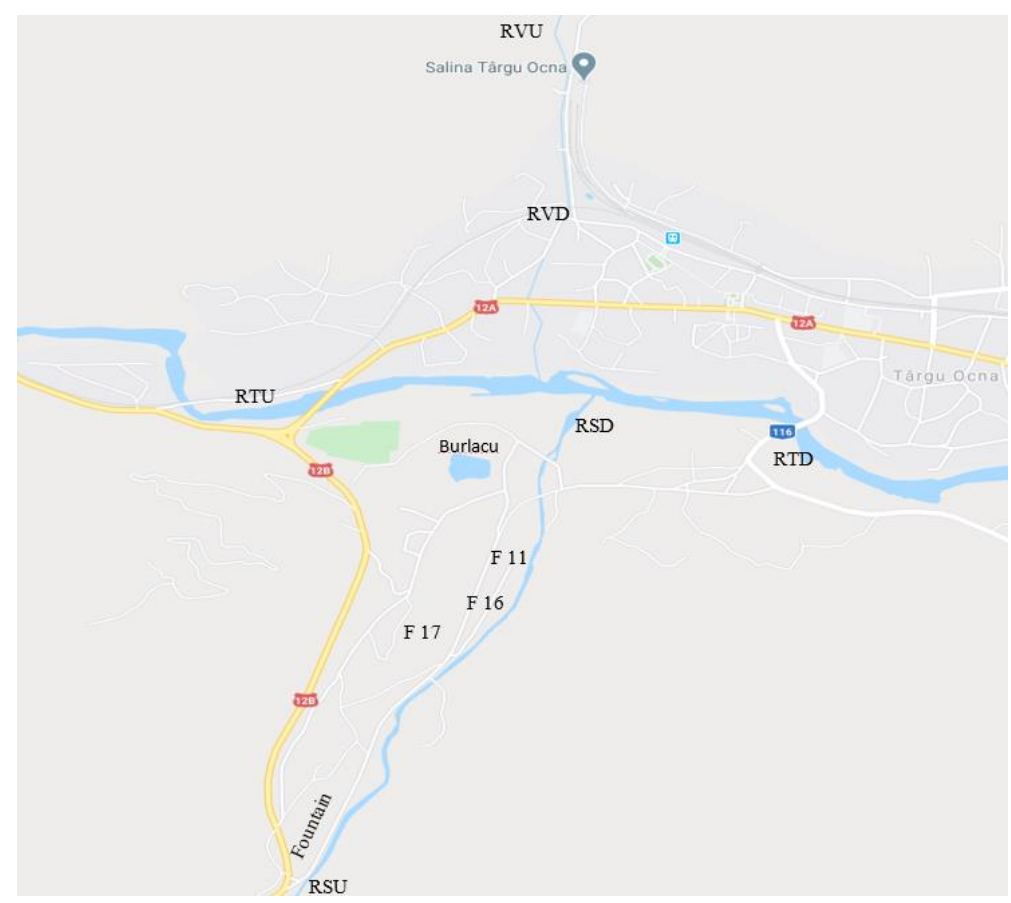

Figure 1. Sampling points location [46]

\subsection{Sampling and analysis}

The collection of samples was carried out in April 2019 in $500 \mathrm{~mL}$ polyethylene (PET) bottles and stored at proper temperature. The equipment's used for parameters evaluations are presented in Table 1.

Physico-chemical parameters measured in-situ were $p \mathrm{H}$, turbidity and dissolved oxygen performed by using portable WTW equipment's. The rest of parameters were evaluated in the Vasile Alecsandri 
University of Bacau laboratory by using DR 3900 spectrophotometer. The standard methods for water parameters determination were: SR EN ISO 10523 for $\mathrm{pH}$, SR EN ISO 5814 for dissolved oxygen and SR EN ISO 7027 for turbidity [47, 48, 49]. Regarding the analysis of rest of the parameters, were used certified methods, recommended by VIS DR 3900 spectrophotometer HACH producer.

Table 1. Evaluated parameters

\begin{tabular}{|c|c|}
\hline Parameters & Used equipment \\
\hline $\mathrm{pH}$ & pH 3210 \\
\hline Temperature & $\mathrm{pH} 3210$ \\
\hline Dissolved Oxygen & Oxi 3210 \\
\hline Turbidity & TURB 430 \\
\hline $\mathrm{Pb}$ & \multirow{13}{*}{ DR 3900 spectrophotometer } \\
\hline $\mathrm{Ni}$ & \\
\hline $\mathrm{Cu}$ & \\
\hline $\mathrm{Fe}$ & \\
\hline $\mathrm{Mn}$ & \\
\hline $\mathrm{Zn}$ & \\
\hline $\mathrm{Cr}$ & \\
\hline $\mathrm{Mg}$ & \\
\hline $\mathrm{SO}_{4}{ }^{2-}$ & \\
\hline $\mathrm{Al}$ & \\
\hline $\mathrm{NO}_{2}^{-}$ & \\
\hline $\mathrm{NO}_{3}^{-}$ & \\
\hline $\mathrm{NH}_{4}^{+}$ & \\
\hline
\end{tabular}

\section{Results and discussions}

\subsection{Evaluation of the parameters performed in situ}

The parameters analyzed in situ were $p \mathrm{H}$, turbidity and dissolved oxygen (Figure 2). As can be seen in Figure 2a, the samples have a $p \mathrm{H}$ value greater than 7.21 to 8.46. In the groundwater $p \mathrm{H}$ varies from 7.21 to 7.82 units $p \mathrm{H}$ and the $p \mathrm{H}$ value of the water samples from the surface water varies from 8.12 to 8.46 units $p \mathrm{H}$. The highest $p \mathrm{H}$ values are recorded at the RSU and Groapa Burlacu sampling points $(8.46$ units $p \mathrm{H})$. The lowest $p \mathrm{H}$ value is recorded at sampling point $\mathrm{F} 17$ having a value of 7.21 units $\mathrm{pH}$. The average $p \mathrm{H}$ value in the studied area indicates that the analyzed samples are weak alkaline.

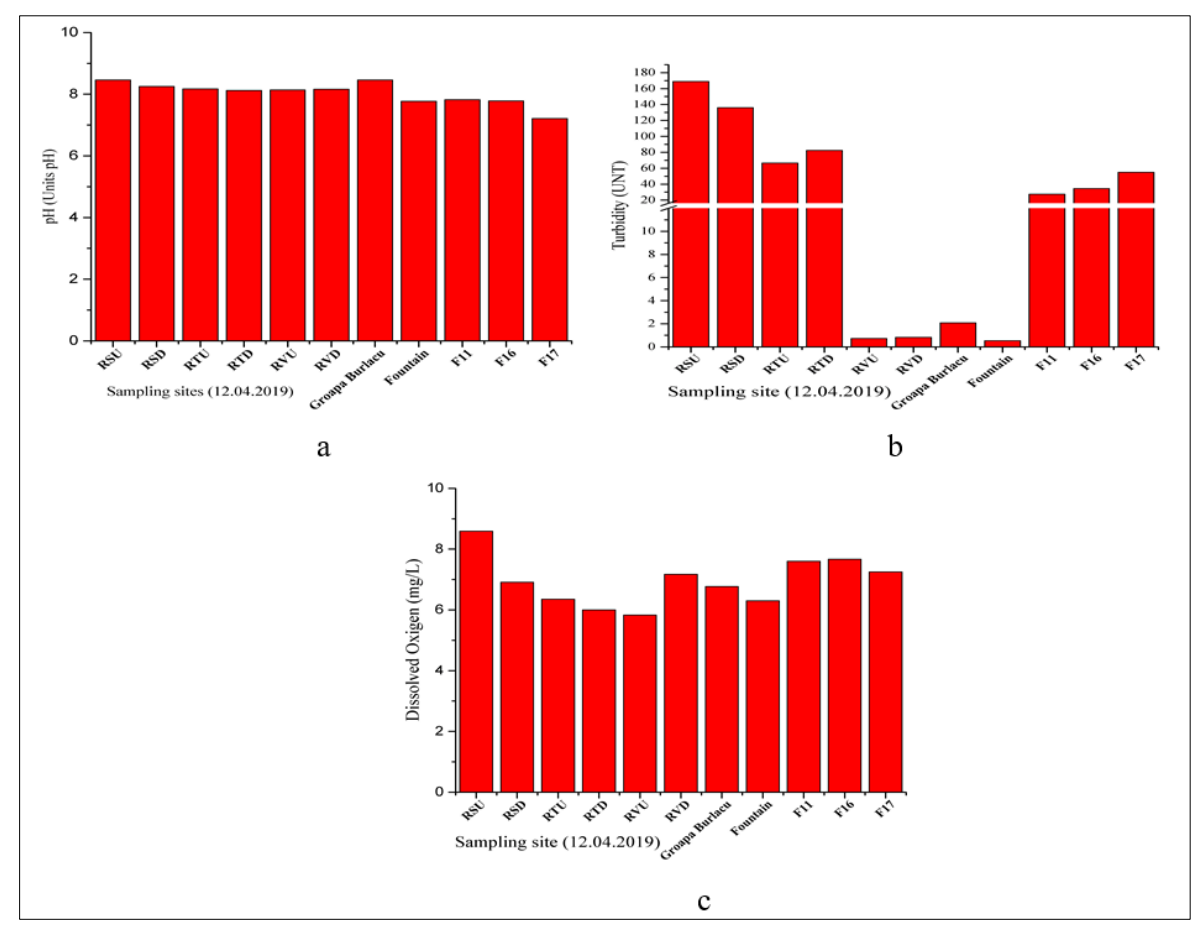

Figure 2. The values of parameters analyzed in situ: $\mathrm{a}-\mathrm{pH} ; \mathrm{b}$ - turbidity; $\mathrm{c}$ - dissolved oxygen 
The turbidity values (Figure 2b) of groundwater varies from 0.54 to 55 NTU recorded at measurement point F17, and the values recorded within surface waters varies from 0.73 to 169 NTU. The highest values are recorded upstream for the RSU measurement point and the lowest values are recorded at the RVU measurement points and in the fountain. The high values recorded for turbidity can be a consequence of the high precipitation level from that period.

The highest values of dissolved oxygen (Figure 2c) for surface waters are recorded in the upstream of RSU and RTU, except for the sample taken from the River Valcele where the highest value is recorded downstream. The value recorded in the measuring point Groapa Burlacu was 6.77 mg/L. Regarding the measurement points taken from the groundwater, the highest values were recorded in points F16 and F11.

\subsection{Evaluation of the parameters performed in laboratory}

Thirteen indicators (Figures 3 and 4) $\mathrm{Ni}, \mathrm{NO}_{3}{ }^{-}, \mathrm{Cu}, \mathrm{Fe}, \mathrm{Mn}, \mathrm{SO}_{4}{ }^{2-}, \mathrm{Pb}, \mathrm{NO}_{2}{ }^{-}, \mathrm{Zn}, \mathrm{Cr}, \mathrm{NH}_{4}{ }^{+}, \mathrm{Al}$ and $\mathrm{Mg}$ were analyzed from the samples of the groundwater and surface water in the Vasile Alecsandri University of Bacau laboratory.

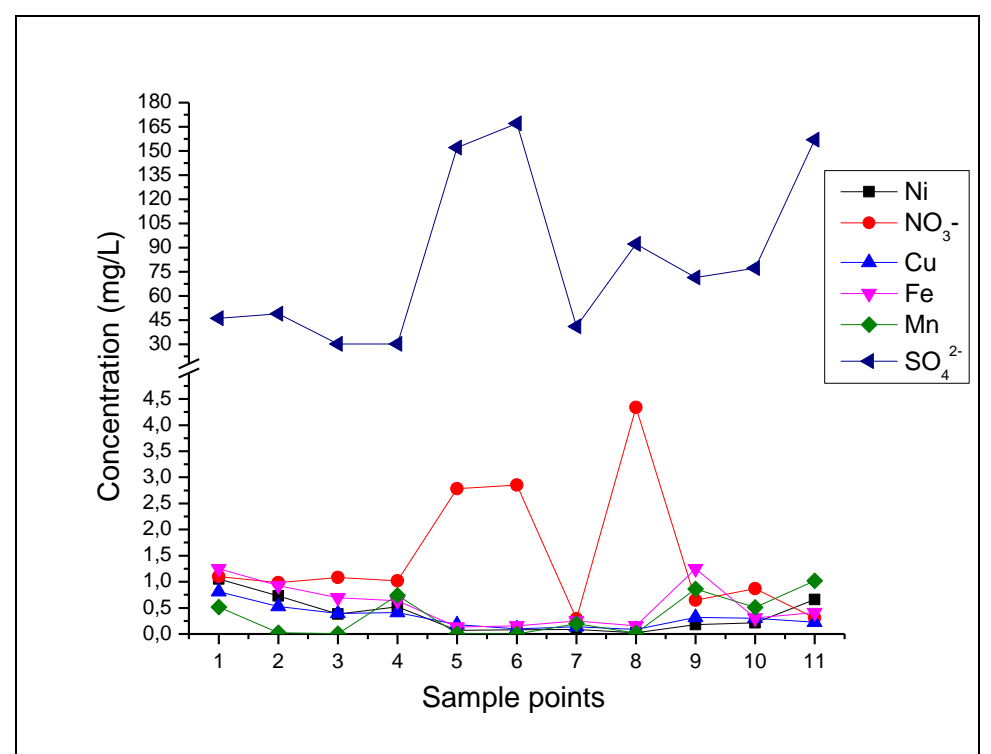

Figure 3. Variation of the $\mathrm{Ni}, \mathrm{NO}_{3}{ }^{-}, \mathrm{Cu}, \mathrm{Fe}, \mathrm{Mn}$ and $\mathrm{SO}_{4}{ }^{2-}$ parameter's evaluated in laboratory: $1-\mathrm{RSU} ; 2-\mathrm{RSD} ; 3-\mathrm{RTU}$; 4 - RTD; 5 - RVU; 6 - RVD; 7 - Groapa Burlacu; 8 - Fountain;

$$
9 \text { - F11; } 10 \text { - F16; } 11 \text { - F17 }
$$

Following the analyzes, the maximum concentrations of Fe were recorded in the RSU and F11 samples respectively $1.25 \mathrm{mg} / \mathrm{L}$ at both measured points.

The result of the analyzes regarding the concentration of $\mathrm{Cu}$ is in the range $0.088 \mathrm{mg} / \mathrm{L}$ to 0.809 $\mathrm{mg} / \mathrm{L}$. The maximum concentration of $\mathrm{Cu}$ was recorded in the RSU sample and the smallest value is present in the sample taken from the fountain.

The value of the maximum concentrations of $\mathrm{Pb}$ (Figure 4) was found in the samples taken from the surface waters, respectively the Groapa Burlacu with a value of $0.095 \mathrm{mg} / \mathrm{L}, \mathrm{RTD}(0.092 \mathrm{mg} / \mathrm{L})$ and RSD (0.086 mg L). Regarding the samples taken from groundwater, the concentrations of $\mathrm{Pb}$ present some constant values between $0.075 \mathrm{mg} / \mathrm{L}$ to $0.081 \mathrm{mg} / \mathrm{L}$.

The small concentrations of $\mathrm{Zn}$ in the analyzed samples were recorded in the samples taken from the groundwater $(0.001 \mathrm{mg} / \mathrm{L}$ to $0.002 \mathrm{mg} / \mathrm{L})$. In the downstream of Slanic River (RSD) the highest value of $\mathrm{Zn}$ concentration recorded was $0.016 \mathrm{mg} / \mathrm{L}$. 


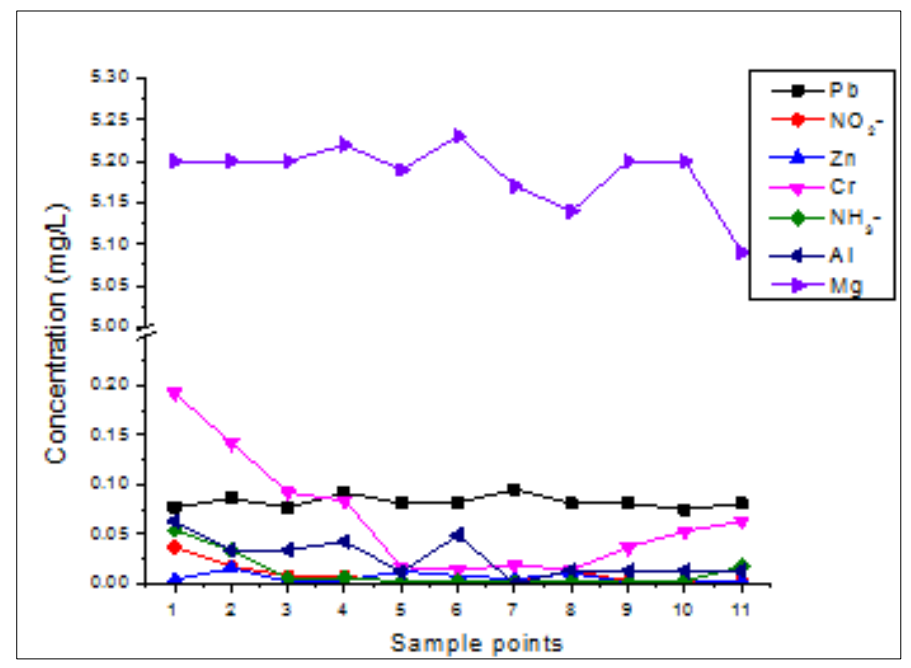

Figure 4. Variation of the $\mathrm{Pb}$, $\mathrm{NO}_{2}{ }^{-}, \mathrm{Zn}, \mathrm{Cr}, \mathrm{NH}_{4}{ }^{+}, \mathrm{Al}$ and $\mathrm{Mg}$ parameter's evaluated in laboratory: 1 - RSU; 2 - RSD; 3 - RTU; 4 - RTD; 5 - RVU; 6 - RVD;7 - Groapa Burlacu; 8 - Fountain; 9 - F11; 10 - F16; 11 - F17

The concentrations of the $\mathrm{NO}_{3}{ }^{-}$values were between $0.290 \mathrm{mg} / \mathrm{L}$ to $2.85 \mathrm{mg} / \mathrm{L}$. The high value of the $\mathrm{NO}_{2}{ }^{-}$and $\mathrm{NO}_{3}{ }^{-}$concentration were recorded in the point $\mathrm{RSU}$. This point is in the incidence of the possible waste and wastewater from near households.

The surface water analyzes results indicate high level of $\mathrm{SO}_{4}, 167 \mathrm{mg} / \mathrm{L}$ to $30.2 \mathrm{mg} / \mathrm{L}$. These values indicate that the water samples are included in the II and III quality class. The samples analyzed from the sampling points RSU, RSD, RTU, RTD and Groapa Burlacu belong to quality class II, and the sampling points RVU and RVD belong to II quality class [50].

In the analyzed samples, the values of $\mathrm{Cr}$ concentrations for surface waters are in the range 0.014 $\mathrm{mg} / \mathrm{L}$ to $0.192 \mathrm{mg} / \mathrm{L}$. Regarding groundwater, the analyzed samples recorded values were in the range $0.014 \mathrm{mg} / \mathrm{L}$ to $0.053 \mathrm{mg} / \mathrm{L}$.

The values for $\mathrm{Mn}$ in some samples analyzed are insignificant, recording values in the range 0.001 $\mathrm{mg} / \mathrm{L}$ to $0.007 \mathrm{mg} / \mathrm{L}$. For RTD measurement points, F11 and F17 the values resulting from the analyzes are in the range $0.742 \mathrm{mg} / \mathrm{L}$ to $1.02 \mathrm{mg} / \mathrm{L}$. Following the analyzes carried out, the results on the analyzed samples indicate a concentration of $\mathrm{Ni}$ value between $0.026 \mathrm{mg} / \mathrm{L}$ to $0.657 \mathrm{mg} / \mathrm{L}$, except for the RSU sample which recorded the value of $1.05 \mathrm{mg} / \mathrm{L}$.

The concentration of $\mathrm{Al}$ for both samples of the surface water and groundwater as a result of the analyzes are in the range of $0.012 \mathrm{mg} / \mathrm{L}$ to $0.063 \mathrm{mg} / \mathrm{L}$. In the water sample taken from Groapa Burlacu point the concentration of $\mathrm{Al}$ is zero.

Regarding the results of the concentration of $\mathrm{Mg}$ the resulting values are relatively constant from $5.09 \mathrm{mg} / \mathrm{L}$ to $5.23 \mathrm{mg} / \mathrm{L}$.

\section{Conclusions}

The study presents a monitoring of groundwater and surface water in the mining area of Targu Ocna, Bacau county.

Following the results, the parameters that were measured for the water quality study show that the maximum $p \mathrm{H}$ value was recorded at the measuring point Groapa Burlacu indicating an alkaline $\mathrm{pH}$.

Domestic activities, waste, weather conditions within the study area may influence the chemical composition of surface and groundwater within the studied area.

The present study evaluates a monitoring of the contamination level of the water sources around the studied area. The results of the analyzed indicators $\left(\mathrm{Pb}, \mathrm{Ni}, \mathrm{Cu}, \mathrm{Fe}, \mathrm{Mn}, \mathrm{Zn}, \mathrm{Cr}, \mathrm{Mg}, \mathrm{SO}_{4}{ }^{2-}, \mathrm{Al}\right.$, $\mathrm{NO}_{2-}, \mathrm{NO}_{3-}$ and $\mathrm{NH}_{4}^{+}$) in the surface and groundwaters vary from sample to sample. The highest concentrations of the analyzed indicators are found in the samples taken from the surface waters, except for the $\mathrm{SO}_{4}{ }^{2-}$ indicator. 
The metal content in the samples of surface water have been in the order $\mathrm{Fe}>\mathrm{Mg}>\mathrm{Ni}>\mathrm{Cu}>\mathrm{Mn}>$ $\mathrm{Pb}>\mathrm{Cr}>\mathrm{Al}>\mathrm{Zn}$ and samples of the groundwater were of the order of $\mathrm{Mg}>\mathrm{Mn}>\mathrm{Fe}>\mathrm{Ni}>\mathrm{Cu}>$ $\mathrm{Pb}>\mathrm{Cr}>\mathrm{Al}>\mathrm{Zn}$.

The concentrations between the cations in the surface waters and the groundwater analyzed are of the order $\mathrm{Mg}>\mathrm{Pb}>\mathrm{Al}$. The anion concentrations were of the order $\mathrm{SO}_{4}{ }^{2-}>\mathrm{NO}_{3}{ }^{-}>\mathrm{NO}_{2}{ }^{-}$for surface and underground waters in the analyzed samples.

\section{References}

1. EBLIN, S. G., KONAN, K. S., MANGOUA, OI M. J., NEDEFF, V., SANDU, A. V., BARSAN, N., SANDU, I., Nitrate Pollution of Groundwater Based on GIS in the City of Daloa, West-central Cote d'Ivoire, Rev.Chim., 70(7), 2019, 2579-2583.

2.BARSAN, N., JOITA, I., STANILA, M., RADU, C., DASCALU M., Modelling wastewater treatment process in a small plant using a Sequencing Batch Reactor (SBR), Environmental Engineering and Management Journal, 13(7), 2014, 1561-1566.

3.BARSAN, N., NEDEFF, V., TEMEA, A., MOSNEGUTU, E., CHITIMUS A.D., TOMOZEI, C., A perspective for poor wastewater infrastructure regions: a small-scale Sequencing Batch Reactor treatment system, Chemistry Journal of Moldova, 12(1), 2017, 61-66.

4.FABIAN, F., NEDEFF, V., BIRSAN, NARCIS, MOSNEGUTU, E., Energy and Chemicals Consumption Evaluation in Water Treatment Plant A comparative study between Bacau and Turin, Rev.Chim., 70(3), 2019, 881-886.

5.IRIMIA, O., TOMOZEI, C., PANAINTE, M., MOSNEGUTU, E. F., BARSAN, N., Efficiency of filters with different filtering materials: comparative study in water treatment, Environmental Engineering and Management Journal, 12(1), 2013, 35-39.

6.BARSAN, N., CHITIMUS, D., NEDEFF, F.M., SANDU, I., MOSNEGUTU, E., SANDU, A.V., TOMOZEI, C., Mathematical Correlations of the Variable Parameters Specific for an SBR Experimental Laboratory Plant, Rev.Chim., 70(12), 2019, 4574-4578.

7.BARSAN, N., CHITIMUS, D., NEDEFF, F.M., SANDU, I., PANAINTE LEHADUS, M., SANDU, A.V., IRIMIA TARTOACA, O., Experimental application of a laboratory SBR plant used for domestic wastewater treatment, Rev.Chim., 70(11), 2019, 4098- 4101.

8.TATARU, L., NEDEFF, V., BARSAN, N., MOSNEGUTU, E., PANAINTELEHADUS, M., SANDU, I., CHITIMUS, D., Studies of Humic Acid Removal from Aqueous Systems by Using Polymeric Membrane Ultrafiltration Process, Mater. Plast., 55(4), 2018, 660-685.

9.TATARU, L., NEDEFF, V., BARSAN, N., SANDU, A. V., MOSNEGUTU, E., PANAINTELEHADUS, M., SANDU, I., Applications of Polymeric Membranes Ultrafiltration Process on the Retention of Bentonite Suspension, Mater. Plast., 56(1), 2019, 97-102.

10.MISAILA, L., NEDEFF, F.M., BARSAN, N., SANDU, I.G., GROSU, L., PATRICIU, O.I., GAVRILA, L., FINARU, A.L., WATERSHED - android application for the mineral waters, classification, Rev.Chim., 70(6), 2019, 2212-2217.

11.UNTILA, C., CARAMAN, M., NEDEFF, V., BARSAN, N., SANDU, I., CHITIMUS, A.D., CRETU, V.V., TOMOZEI, C., SANDU, A.V., Evaluation of heavy metals and organic compounds in water samples collected from various sources from Republic of Moldova and Romania, Rev.Chim., 70(10), 2019, 3570-3574.

12.ROMANESCU, G., ZAHARIA, C., SANDU, A.V., JURAVLE, D.T., The Annual and MultiAnnual Variation of the Minimum Discharge in The Miletin Catchment (Romania). An Important Issue of Water Conservation, International Journal of Conservation Science, 6(4), 2015, 729-746.

13.ROMANESCU, G., MIFTODE, D., MIHU-PINTILIE, A., STOLERIU, C.C., SANDU, I., Water quality analysis in mountain freshwater: Poiana Uzului reservoir in the Eastern Carpathians, Rev.Chim., 67(11), 2016, 2318- 2326.

14.BOCIORT, D., GHERASIMESCU, C., BERARIU, R., BUTNARU, R., BRANZILA, M., SANDU, I., Comparative Studies on Making the Underground Raw Water Drinkable, by Coagulation- 
Flocculation and Adsorption on Granular Ferric Hydroxide Processes, Rev.Chim., 63(12), 2012, 1243 1248.

15.CIDU, R., BIAGINI, C., FANFANI, L., LA RUFFA, G., MARRAS, I., Mine closure at Monteponi (Italy): Effect of the cessation of dewatering on the quality of shallow groundwater, Applied Geochemistry, 16, 2001, 489-502.

16.HAMED, A. EL-SEREHY, HALA, S.A., FAHAD, A. AL-MISNED, SALEH, A. AL-FARRAJ, KHALED, A. AL-RASHEID, Assessing water quality and classifying trophic status for scientifically based managing the water resources of the Lake Timsah, the lake with salinity stratification along the Suez Canal, Saudi Journal of Biological Sciences, 25(7), 2018, 1247-1256.

17.BALAL ARAIN, M., ULLAH, I., NIAZ, A., SHAH, N., SHAH, A., HUSSAIN, Z., TARIQ, M., IMRAN AFRIDI, H., AHMAD BAIG, J., GUL KAZI, T., Evaluation of water quality parameters in drinking water of district Bannu, Pakistan, Multivariate study, Sustainability of Water Quality and Ecology, 3-4, 2014, 114-123. DOI:10.1016/j.swaqe.2014.12.005.

18.COCHIORCA, A., BARSAN, N., NEDEFF, F.M., SANDU, I., MOSNEGUTU, E.F., PANAINTE LEHADUS, M., CHITIMUS, D., IRIMIA, O., SANDU, I.G., Surface water quality assessment from a mining area case study, Groapa Burlacu lake, Targu Ocna, Romania, Rev.Chim., 70(10), 2019, 36783680 .

19. IAVAZZO, P., DANIELA, D., PAOLA, A., MARCO, T., ANTONELlO, M., BONI, M., Impact of Past Mining Activity on the Quality of Water and Soil in the High Moulouya Valley (Morocco), Water Air Soil Pollution, 223, 2012, 573-589.

20.CIDU, R., BIDDAU, R., FANFANI, L., Impact of past mining activity on the quality of groundwater in SW Sardinia (Italy), Journal of Geochemical Exploration, 100, 2009, 125-132.

21.SINGH, K. P., MALIK, A., MOHAN, D., SINHA, S., Multivariate statistical techniques for the evaluation of spatial and temporal variations in water quality of Gomti River (India) - a case study, Water Resources, 38, 2004, 3980-3992.

22. XIUZHEN, H., DENGJUN, W., PEIRAN, W., YUXIA, W., DONGMEI, Z., Evaluation of water quality in surface water and shallow groundwater: a case study of a rare earth mining area in southern Jiangxi Province, China, Environ. Monitoring Assess, 24, 2016, 188.

23.COCHIORCA, A., NEDEFF, V., BARSAN, N., MOSNEGUTU, E.F., PANAINTE LEHADUS, M., TOMOZEI, C., Analysis of water quality for two rivers located near a mining area, Chemistry \& Chemical Engineering, Biotechnology, Food Industry, 19(4), 2018, 455-463.

24.EBLIN, S.G., ANOH, K.A., YAO, A.B., SORO, N., NEDEFF, V., MOSNEGUTU, E., SANDU, A.V., Mapping Groundwater Vulnerability to Pollution in the Region of Adiake, Southeast Coastal of Cote D ivoire: A Comparative Study of three (3) Methods, International Journal of Conservation Science, 10(3), 2019, 493-506.

25.BOCIORT, D., GHERASIMESCU, C., BERARIU, R., BUTNARU, R., BRANZILA, M., SANDU, I., Research on the Degree of Contamination of Surface and Groundwater used as Sources for Drinking Water Production, Rev.Chim., 63(11), 2012, 1152-1157.

26.GUPTA, P., SARMA, K., Spatial Distribution of Groundwater Quality, Depth and Plant Species Diversity in National Capital Territory (NCT) of Delhi, India, International Journal of Conservation Science, 9(2), 2018, 351-360.

27.ROMANESCU, G., TIRNOVAN, A., COJOC, G.M., SANDU, I.G., Temporal Variability of Minimum Liquid Discharge in Suha Basin. Secure Water Resources and Preservation Possibilities, International Journal of Conservation Science, 7(4), 2016, 1135-1144.

28.MOGA, I.C., MATACHE, M.G., COVALIU, I.C., Advanced wastewater treatment stage for textile industry, Industria Textila, 69, 2018, 478-482.

29.ROMANESCU, G., TARNOVAN, A., SANDU, I.G., COJOC, G.M., DASCALITA, D., SANDU, I., The Quality of Surface Waters in the Suha Hydrographic Basin (Oriental Carpathian Mountains), Rev.Chim., 65(10), 2014, 1168- 1171. 
30.DIPPONG, T., MIHALI, C., HOAGHIA, M.A., CICAL, E., COSMA, A., Chemical modeling of groundwater quality in the aquifer of Seini town Somes Plain, Northwestern Romania, Ecotoxicology and Environmental Safety, 168, 2019, 88-101.

31.***Directive 2006/118/EC of the European Parliament and of the Council of 12 December 2006 on the protection of groundwater against pollution and deterioration.

32.FARMAKI, E.G., THOMAIDIS, N.S., Current status of the metal pollution of the environment of Greece - a review, Global NEST Journal, 10, 2008, 366-375.

33.FAROZ AHMAD, A., HARENDRA, K.S., MAKHMOOR AHMAD, R., RAO, R.J., Impact of mining activities on various environmental attributes with specific reference to health impacts in Shatabdipuram, Gwalior, India, International Research Journal of Environment Science, 3(6), 2014, 81-87.

34.GRIEBLER, C., AVRAMOV, M., Groundwater ecosystem services: a review, Freshw. Sci., 34(1), 2015, 355-367.

35.HUTTON, M., SYMON, C., The quantities of cadmium, lead, mercury and arsenic entering the U.K. environment from human activities, Sci. Total Environ., 57, 1986, 129-150.

36.JARUP, L., Hazards of heavy metal contamination, Br. Med. Bull., 68, 2003, 167-182.

37.KUMAR MOHANTY A., LINGASWAMY, M., RAO, G.VVS, SANKARAN, S., Impact of acid mine drainage and hydrogeochemical studies in a part of Rajrappa coal mining area of Ramgarh District, Jharkhand State of India, Groundwater for Sustainable Development, 7, 2018, 164-175.

38. NAKAGAWA, K., AMANO, H., TAKAO, Y., HOSONO, T., BERNDTSSON, R., J. On the use of coprostanol to identify source of nitrate pollution in groundwater, J. Hydrol., 550, 2017, 663-668.

39.SEMERDON, B., DREWES, J.E., Groundwater recharge: the intersection between humanity and hydrogeology, J. Hydrol., 555, 2017, 909-911.

40.SINGH, A.K., MAHATO, M.K., NEOGI, B., MONDAL, G.C., SINGH, T.B., Hydrogeochemistry, elemental flux and quality assessment of mine water in the Pootkee-Balihari mining area, Jharia coalfield, India, Mine Water and the Environment, 30(3), 2011, 197-207.

41.SHAKERKHATIBI, M., MOSAFERI, M., POURAKBAR, M., AHMADNEJAD, M., SAFAVI, N., BANITORAB, F., Comprehensive investigation of groundwater quality in the north-west of Iran: Physicochemical and heavy metal analysis, Groundwater for Sustainable Development, 8, 2019, 156168.

42.TIWARI, A.K., SINGH, P.K., MAHATO, M.K., Hydrogeochemical investigation and qualitative assessment of surface water resources in West Bokaro Coalfield, India, J. Geol. Soc. India, 87, 2016, 85-96.

43.WU, J., SU, Z., Evaluation of shallow groundwater contamination and associated human health risk in an alluvial plain impacted by agricultural and industrial activities, Mid-West China, Exposure and Health, 8, 2016, 311-329.

44.YUAN, Y., LIANG, D., ZHU, H., Optimal control of groundwater pollution combined with source abatement costs and taxes, J. Comput. Sci., 20, 2017, 17-29.

45. ZAHEDI S., AZARNIVAND A., CHITSAZ N., Groundwater quality classification derivation using multi-criteria-decision-making techniques, Ecol. Indic., 78, 2017, 243-252.

46.***http://www.google.com/maps, Available online: (accessed on: 17.07.2019).

47.***SR EN ISO 10523:2012, Water quality. Determination of $\mathrm{pH}$.

48.***SR EN ISO 5814:2013, Water quality. Determination of dissolved oxygen content. Electrochemical method with probe.

49.***SR EN ISO 7027:2001, Water quality. Determination of turbidity.

50.***Romanian Law no. 161/2006, (in Romanian) Classification of surface water quality in order to establish the ecological status of water bodies.

$\overline{\text { Manuscript received: } 17.02 .2020}$ 